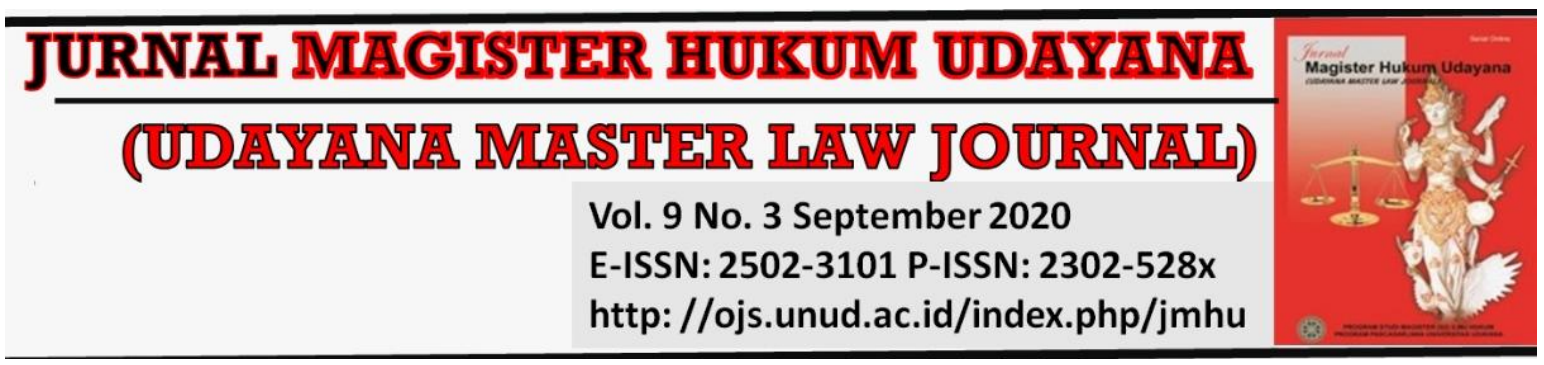

\title{
Surveillance Urgency to Prevent Village Fund Corruption
}

\author{
I Ketut Rai Setiabudhi' ${ }^{\text {, I Putu Rasmadi Arsha Putra }}{ }^{2}$
}

1Faculty of Law, Udayana University, E-mail: rai_setiabudhi@unud.ac.id / raisetiabudhi_fhunud@yahoo.com

2Faculty of Law, Udayana University, E-mail: putu_rasmadi@unud.ac.id / rasmadifh@gmail.com

\begin{tabular}{l}
\hline Info Article \\
\hline Received: $29^{\text {th }}$ November 2019 \\
Accepted: $26^{\text {th }}$ September 2020 \\
Published: $30^{\text {th }}$ September 2020 \\
Keywords: \\
Surveillance; Supervision; \\
Village Fund Corruption \\
\\
Corresponding Author: \\
I Ketut Rai Setiabudhi \\
E-mail: : \\
rai_setiabudhi@unud.ac.id/ \\
raisetiabudhi_fhunud@yahoo.co \\
m \\
DOI: \\
10.24843/JMHU.2020.v09.i03. \\
p01
\end{tabular}

\section{Abstract}

This study aims to understand and analyze what is potential for corruption in village funds, and how Prevention Efforts Against Village Funds Irregularities to develop mechanisms and observe symptoms that appear to have a tendency to indicate danger as an effort to prevent irregularities in village funds that can cause losses to the state so it needs to watch out. This study uses normative legal research methods supported by empirical research. In an effort to approach using the statutory approach which has links to issues of financial oversight, corruption, villages and related to the management of village funds. The results of this study are that several things could potentially lead to corruption in village funds that can harm state finances, including the first being the village government's unpreparedness in managing village funds, second is in terms of planning that does not involve the community and the lack of involvement of the Village Consultative Agency, third implementation, in this case, the implementation of the use of village funds is still many do not follow the existing procedures and the politicization of the budget, and the fourth is accountability. In the case of efforts to prevent misuse of village funds, a preventative effort is needed so that a regulatory regulation is needed to avoid undesirable things that can disrupt and harm state finances.
\end{abstract}

\section{Introduction}

The change of government also affects the change the government programs. One of the current government programs is to move Indonesia's development which was originally from the center of the city moved to the suburbs with the village empowerment which is arranged in the unity of the Republic of Indonesia, which has been stated in the $6^{\text {th }}$ Nawa Cita. The advancement of the country can be determined by how advanced the village is, the village has both natural and human resources. There will be no advancement in a country without the advancement of the province and there will be no advancement in the province without the advancement in the district, and also there will be no advancement in the district of the city without any advancement that comes from the village. The enactment of Law of The Republic of Indonesia Number 6 of 2014 concerning village (hereinafter 
referred to as Village Law) landmarks the national legislation to reinforce the status of the village as the center of the village society administration as well as a basis for advancing end empowering rural communities in contributing to increasing national economic growth.

This condition continues to be organized and built with the arrangements regarding village allocation funds in the Village Law. It is known that the village has income from various sources. In article 71 paragraph (1) of Village Law, it is stated that village finances are all village rights and obligations that can be valued in money, as well as all things and items related to the implementation of village rights and obligations. In organizing the village fund management in the village administration, it is always based on the principles of good governance and in line with the principles of village regulation as mandated in Village Law, including having legal certainty, maintaining good governance, public order, openness, professionalism, accountability, effectiveness, efficiency, local wisdom, and promoting diversity and community participation. In addition to upholding the principle, the implementation of village development also prioritizes the value of togetherness, kindship, and mutual cooperation to achieve social justice and peace. The receipt from each source of village income must be based on law and must be recorded orderly accompanied by proof of receipt. Likewise, the use of village funds must comply with existing regulations and in the event of irregularities and misappropriation of the village, funds will lead to corruption.

Corruption has been classified as an extraordinary crime because corruption causing extraordinary impacts occur systemically and extensively, detrimental to the country's finances, disturb the stability, and security of the society and able to undermine the values of democracy, ethics, justice, and legal certainty and violate the social-economic rights of the society widely. ${ }^{1}$ Serikat Putrajaya contends that it must be recognized that Indonesia always puts itself at the top of the rank of countries that prone to corruption. This is supported by the result of the research conducted by Transparency International and Political and Economic Risk Consultancy based in Hong Kong2. From the above opinion, it can be said that this country has been entwined with the root of all existing evil, this is due to the low accountability of the public bureaucracy, where the public bureaucracy which is supposed to be a public servant is indicated as a hotbed of corruption. This is supported by the opinion of Arbi Sanit, that bureaucratic actors have the enormous authority that can lead to a dichotomy between policymakers and implementers so that the bureaucracy seems to prioritize an attitude of control rather than as a public servant. If we look at the

\footnotetext{
${ }^{1}$ Sosiawan, U. M. (2019). Peran Komisi Pemberantasan Korupsi (KPK) dalam pencegahan dan pemberantasan korupsi. Jurnal Penelitian Hukum De Jure, 19(4), 517-538. DOI: http:/ / dx.doi.org/10.30641/dejure.2019.V19.517-538

${ }^{2}$ Khaidir, K., Abdullah, M., \& Achmad, R. (2017). Kebijakan Hukum Pidana Dalam Pemberantasan Tindak Pidana Korupsi (Tinjauan Analisis Terhadap Pembalikan Beban Pembuktian Dalam UU Nomor 20 Tahun 2001). Legalitas: Jurnal Hukum, 1(5), 92-131. DOI: http://dx.doi.org/10.33087/legalitas.v1i5.78
} 
existence of the bureaucracy of public service today. What is seen is that power and authority become an undeniable factor for its proximity to corruption ${ }^{3}$.

The government did not stay silent, by carrying out bureaucratic reforms, and waging a war on corruption. ${ }^{4}$ Corruption eradication starts from the executive, legislative and judicial levels. ${ }^{5}$ The role of the Corruption Eradication Commission (hereinafter referred to as the KPK) has increased significantly, with a pattern of eradication that is structured, sanctions and deterrent effects for corruption perpetrators are always enhanced. This is done with the aim of efficiency and effectiveness in handling corruption in Indonesia.

The role of the KPK seems to need to be increased to the regions because the people are waiting for the presence of the KPK in the regions moreover corruption seems to have migrated from the central government to the lower level of government, such as regional and village governments. It seems that this is due to the shifting concentration of development in Indonesia, in the current era of development is prioritized in border areas and villages. If we can assume that corruption is like an ant, where there is sugar there are ants, corruption does not only touch the realm of government but has reached the environment of justice, education, companies, and all aspects of life. Seeing the phenomenon that is currently growing in Indonesia is certainly worrying if structured corruption has become a culture in a bureaucracy. Even corruption is no longer carried out individually-traditionally but has been carried out communally-professionally starting from the determination of projects, and budgeting. ${ }^{6}$ Corruption can create a very strong systemic network in the bureaucratic environment in Indonesia. ${ }^{7}$ Therefore, we need research that examines a bureaucratic culture in Indonesia in order to find a formulation in an effort to eradicate corruption. Eradicating corruption is a top priority for this country, fighting poverty, improving education and public health will not be able to be realized if corruption is still rampant in this beloved country. Especially until it spreads to villages that are currently flowing with lager funds, of course, this needs to prevent, because prevention is better than cure.

${ }^{3}$ Hadi. K. (2016) Korupsi Birokrasi Pelayanan Publik di Era Otonomi Daerah. Jurnal Penelitian Politik, 7 (1), h. 20.

${ }^{4}$ Alkostar, A. (2008). Mengkritisi fenomena korupsi di parlemen. Jurnal Hukum IUS QUIA IUSTUM, 15(1) DOI: https://doi.org/10.20885/iustum.vol15.iss1.art2

${ }^{5}$ Nastiti, N. N., Djemat, Y. O., \& Dwiprigitaningtias, I. (2017). Tantangan Implementasi Kerjasama Anti-Terorisme Antara Indonesia dan Australia Tahun 2007-2016. Jurnal Dinamika Global, 2(02), 68112.

${ }^{6}$ Milono, A. (2014). Formulasi Pedoman Penjatuhan Sanksi Pidana terhadap Penyelenggara Negara yang Melakukan Tindak Pidana Korupsi di Indonesia. Arena Hukum, 7(1), 117-130. DOI https://doi.org/10.21776/ub.arenahukum.2014.00701.7

7 Anggraeni, T. D. (2014). Menciptakan sistem pelayanan publik yang baik: Strategi reformasi birokrasi dalam pemberantasan korupsi. Jurnal Rechts Vinding: Media Pembinaan Hukum Nasional, 3(3), 417-433. 
It raises concern for many parties with the enactment of the Village Law, relating to village financial management, which includes village resource management. Management of village funds regulated in the Village Law requires a preparedness of village officials in implementing them. Various reasons and factors are of concern to many parties related to the readiness of village officials, supporting infrastructure, and accountable bureaucracy. The Village Law gives autonomous authority to the village government in managing and developing the village. The village government can improve the village economy by forming Village-Owned Enterprises (hereinafter referred to as the BUMDes), arranging the Village Budget and Expenditure (hereinafter referred to as the APBDes), and carrying out various infrastructure developments that can support the improvement of the village economy. With such great autonomy, the village government has an even greater job of preventing corruption in the management of village funds. The Indonesian government has always been aggressively working to prevent and eradicate corruption. As we all know, the Indonesian government does not only stand idle in terms of eradicating corruption, starting from the aspect of regulation, institutional empowerment, and even the formation of special institutions but if we look more deeply the eradication action places more emphasis on actions against something that has already happened (repressive), actually it is better to do prevention earlier. Prevention is very important to reduce the occurrence of corruption. With the village funds, prevention should be done early so that there is no misuse of village financial management.

This research will examine a different part of the research that has been done before, which has the same study of corruption and village funds. Some of the previous papers that have been related to corruption and village funds can be described as follows; the first was a research conducted by Agung Honesta Yuristyan Sayuti, Jazim Hamidi, and Muhammad Dahlan, conducted in 2014, that focuses on village government supervision system under the Law Number 6 of 2014 concerning Village and its reconstruction of a village government supervision system based on Law Number 6 of 2014 concerning village based on the principles of Good Village Governance. ${ }^{8}$ Secondly, research by Yuyun Yulianah 2017, entitled The Potential Abuse of Village Fund Allocations studied according to Minister of Domestic Affairs Regulation No. 37 of 2017 concerning Village Financial Management, the subject of the study was the policy of implementing village fund allocation and the efforts of local governments to minimize the potential occurrence misappropriation of village fund allocations. ${ }^{9}$

The purpose of this research is to systematically analyze several things that could potentially lead to corruption in village funds, and how Prevention Efforts Against Irregularities in Village Funds to develop a monitoring mechanism as a preventive measure

8 Sayuti, A. H. Y. (2014) Rekonstruksi Sistem Pengawasan Pemerintah Desa Berdasarkan UndangUndang Nomor 6 Tahun 2014 tentang Desa Berbasis Prinsip Good Village Governance. Kumpulan Jurnal Mahasiswa Fakultas Hukum, 1 (1).

${ }^{9}$ Yulianah, Y. (2017). Potensi Penyelewengan Alokasi Dana Desa di Kaji Menurut Peraturan Menteri dalam Negeri Nomor 37 Tahun 2017 tentang Pengelolaan Keuangan Desa. Jurnal Hukum Mimbar Justitia 1(2), 608-627. 
for irregularities in the financial management of village funds in Indonesia, especially in the Province of Bali in order to avoid corruption.

\section{Research Method}

This research is normative legal research and supported by empirical legal research. Normative research is research looking for answers to problems and research objectives based on normative legal theories, which are used to examine data are theories commonly known in doctrinal legal theory, such as legal norms, legal principles, legal understandings, etc. ${ }^{10}$ This study uses a statute approach specifically legislation related to financial supervision, criminal acts of corruption, villages, and village funds, in addition this study also uses a conceptual approach, which is a search concerning the contextual relationship between the laws and regulations that have to do with the supervision techniques carried out by the government to avoid the occurrence of criminal acts in corruption of village funds. Besides the normative method, empirical research is also used. In this case, field research was carried out, especially in several villages in Bali with interview techniques, both structured and free or open. The legal materials that have been collected are analyzed with analysis techniques including description techniques, interpretation techniques, evaluation techniques, and argumentation techniques.

\section{Results and Discussion}

\subsection{Potential for Village Fund Corruption}

As a consequence of the enactment of the Village Law, there are billions of rupiah in funds directly to the village sourced from the Village fund allocation which is part of the balance funds received by the regency/city. This huge amount of funds raises the concerns of several parties because they are prone to being diverted or corrupted.11 What is the actual mechanism for supervising the use of the Village Fund Allocation, in Government Regulation of the Republic of Indonesia Number 8 of 2016 about second change to Government Regulation Number 60 of 2014 concerning Village Funds Sourcing from the State Revenue And Expenditure Budget (hereinafter referred to as PP Village Funds) Article 1, paragraph 2: Village Funds are funds sourced from the State Revenue and Expenditure Budget allocated for Villages which are transferred through the district / city Regional Revenue and Expenditure Budget and are used to finance government administration, development implementation, community development, and community empowerment. The village Fund distribution process is transferred through the regency/city (hereinafter referred to as APBD) to be subsequently transferred to APBDes.

In principle, one aspect of the State Budget (hereinafter referred to as APBN) is the distribution function. In this function, the APBN is implemented to support economic

${ }^{10}$ Anggono, B. D. (2020). Omnibus Law Sebagai Teknik Pembentukan Undang-Undang: Peluang Adopsi Dan Tantangannya Dalam Sistem Perundang-Undangan Indonesia. Jurnal RechtsVinding, 9(1).

${ }^{11}$ Roza, D., \& Arliman, L. (2017). Peran Badan Permusyawaratan Desa di Dalam Pembangunan Desa dan Pengawasan Keuangan Desa. Padjadjaran Journal of Law, 4(3), 606-624. DOI: https:// doi.org/10.22304/pjih.v4n3.a10 
equality between regions so that the gap between one region and another will be reduced including equality between cities and villages in the regions. One application of the APBN distribution function is the transfer of village funds. Based on the PP Village Funds, the source of village funds is from the APBN which is intended for villages that are transferred through the district / city APBD and is used to finance governance, development implementation, community development, and community empowerment. For this reason, supervision and use of village funds require supervision from both the government and the community. The need for supervision is supported by a variety of factors that are potential causes of corruption in village funds including the following.

\subsubsection{Village Government Readiness}

The villager has the impression of being a group of people who lived traditionally, experiencing many disadvantages compared to the people who lived in the cities. Therefore, the Government's program in developing rural areas aim to equalize the welfare conditions of rural and urban communities in accordance with the natural conditions and potential of the village. In carry out village development, there are several numbers of things that need attention related to the readiness of the village including the background of approaches, concepts and realities that occur in each village which can be described as follows:

1. To advanced the development of the villager there are many obstacles found, as is known that Indonesia has a very wide variety of villages from Sabang to Merauke that need attention from the Government. In addition, an important point in carrying out regional autonomy is located in the district which will strengthen the character of the village under its supervision;

2. There is technical assistance needed for village officers, as the front guard in village development. The technical assistance needed is training such as, how to make the right planning, how to implement the plan, financial management that meets the accounting standard and how to make an accountability report;

3. The welfare of the Head of Village and Village Officers need to get attention, welfare is not always viewed from income but can be seen in terms of skills, abilities to lead the village that need to become a concern for the Government;

4. Village Government management skills starting from planning, implementation, supervision to the reporting level are still using a traditional method although in Bali, many people have been able to use modern technology;

5. The mechanism of coordination and synchronization of work between the Government of the Village and the Regional Government and the above level of Government that needs an integrated mechanism. This aims to deliver the plan submitted by the village and its people to the top level and be able to realized properly without any modification or change of its main purpose in the interests of the village; 
6. Utilization of funds through cross-sectoral cannot feel yet by the villager, this requires a strong effort to utilize the mechanism of the village development project;

7. Lack of Cross-sectoral coordination related to the integration of the program, the vision and the mission in Village Government development. This happened because each sector has an ideal vision and mission-related rural development so they think they don't have the authority to interfere with the other sectors. Therefore, we need coordination and synchronization between sectors in village development.

The existence of the Village Law is expected to make an independent village to change the society's point of view that the village is not only as: a). the object of the beneficiary but also be able to give a good impact on the local society; b). local assets development as a living source of society that is organized by all village components with its potential; c). suppliers of the society such as energy, basic community services and others that are carried out independently or in collaboration; d). jobs provider and income source for the society and also for the rural communities to meet the needs of village governance. In addition, the potential for corruption can be revealed from the patrimonial bureaucratic structure at the village level, especially in Asian countries, the patrimonial culture breaks up the boundaries between public and private spaces. ${ }^{12}$ In response to the chaotic problems that exist in the Indonesian bureaucratic system with the strong patrimonialism in Indonesia, which has implications for systemic corruption, not only requires repressive measures to eradicate corruption, but also needs to reform the whole bureaucratic system, not only at the technical level, but also paradigm. ${ }^{13}$

\subsubsection{Planning}

Planning has a very strategic role in realizing advanced and independent village development. Targeted planning needs to carry out in all activities starting from the APBDes, legal basis, the activity program, the implementation schedule, implementing activities, budget, as well as the targets to be achieved to those programs. The planning should be well discussed according to the existing regulations.

In planning the amount of the budget allocated in each proposed program of activity will certainly be carried out in-depth and detailed assessment of the feasibility or the reasonableness of the expenditure budget so that it is really efficient or not excessive which results in a waste of the budget, and vice versa avoiding the occurrence of budget shortages in when the program runs, the result cannot be completed or continued (stalled). But often in the planning process this is a factor causing corruption of village funds, this is triggered by the lack of role and involvement of the community in the process of planning and overseeing village budgets, not optimal village institutions such as the Village Consultative Body and Village Consultation (hereinafter referred to as BPD).

\subsubsection{Implementation}

12 Rahman, F. (2011). Korupsi di tingkat desa. governance, 2(1), 13-24.

13 Djafar, W. (2018). Memotong Warisan Birokrasi Masa Lalu, Menciptakan Demarkasi Bebas Korupsi (Deducting Bureaucracy Legacy Of The Past, Creating A Free Corruption Demarcation). Jurnal Legislasi Indonesia, 8(2), 321-336. 
Development becomes a process of change that's started by a movement from the traditional situation to an advanced modern situation, this will be new things for the society so the society needs to adjust the condition, which called transformation, transformation occurs through the introduction of one or several phases of something that is not known yet exist into existence. In rural community development requires a process of formulation and transformation model that is from the old model to the new model that will be used as an objective of the development process. Besides it also requires an understanding that the development process is an optimistic concept to provide hope for those who voluntarily participate in the process of implementing development. So that the implementation of development both in the social and cultural fields need a change that will be the needs and demands of the villager that will always develop and innovative like the community in general. For this reason, the implementation of development in accordance with the plan becomes very important for the realization of the objectives of the development itself. The implementation of this development requires intensive and fairly strict supervision, especially in the use of the budget.

It is necessary to have a development planning mechanism that starts with the most basic system. The development process that is carried out is a manifestation of the desires of the villager, so it is needed coordination that is built by the Government of the village together with their above level such as district and regency Government that carried out intensively. The implementation of development must also improve the village as the subject of development so that it does not always wrestle as an object of development, what is meant by the object of development is the whole village consist of potential human resources, natural resources and all aspects of life that exist in the village, as well as the technology applied. With a structured implementation, we hope that villages will be included in the classification of self-sufficient villages, which develop with significantly improved the standards of living and society welfare. Villagers largely depend on the agricultural sector, so the target that needs to be achieved is meet the needs of foods by referring to improve the standards of living of rural society by maximizing the skills improvement in the agricultural sector, agricultural industry, and other small industries that support the benefits of agricultural products.

Several things need to get the focus of attention in implementing the budget such as:

1. All types of village revenues and expenditures in the implementation of village authority are carried out through village bank account;

2. For the village whose territory does not have banking service yet, the regulations are determined by the Government of the regency;

3. All the needs of revenue and expenditure carried out by the village must be supported by complete and valid evidence in accordance with the applicable regulations;

4. The Government of the Village is prohibited to do all types of levies apart what is specified in the APDes; 
5. The treasurer is allowed to keep a certain amount of money in the village treasury to meet the operational needs of the village administration, in accordance with the applicable regulations in reget or mayor regulations;

6. Village expenditures contained in the APBDes are determined to be village regulations, except for the interest of personnel expenditure that is binding and for office operational costs stipulated in the Head of Village regulations;

7. The use of expenditure that is intended for unexpected needs must be made the Budgeting Plan that has been approved by the Head of the Village;

8. In submitting funding proposal, it must be completed by Budgeting Plan that verified by the secretary of the village and approved by Head of the Village;

9. Make accountability report for expenditures that cause burdens to the budget that recorded on a book as the accountability report to Head of the Village;

10. Submit an invoice to the Head of the Village completed with the Budgeting Plan and a statement of expenditure responsibility and proof of transaction;

11. The invoice can not be signed before the goods and services are received;

12. Related to the invoice, the secretary of the village as the coordinator of the village financial organizer has an obligation to examine the invoice submitted by the organizing committee of the activity;

13. Examine the invoice;

14. To check the availability of the funds and refusing if the proposal does not meet the requirements determined by the result of verification by the Secretary of the Village;

15. The Treasurer does the payments and record the expenses, and must submitted all the collected tax revenue to the State Treasury Account in accordance with the laws and regulation;

16. The Treasurer makes monthly accountability report to the Head of the Village no later than the next 10 months;

17. Submit the realization of the APBDes report to the regents or mayors, in the form of semester reports.

In addition to the above that need to be considered in the budget implementation process, budget distribution can also be a potential for corruption. Village Funds and Village Fund Allocations (hereinafter referred to as ADD) are two village budgets which have vulnerabilities to be misused for the benefit of Regional Head Elections. The village head is seen to have a strong influence and is a figure that is seen by the community so that the politicization of the use of village funds becomes an effective weapon. ${ }^{14}$

\subsubsection{The Accountability of APBDes Implementation}

It is an obligation to the State Officers or Government who has carried out the obligations in using the budget to account for the implementation of the budget in accordance with the existing regulatory mechanism in the form of village financial accountability. In accordance with the provisions stipulated in the Village Law, villages have several sources of income in the form of the original income of the village, revenue sharing from regional levies of the regencies/cities, distribution of central and regional financial balance funds received by

${ }^{14}$ Kadir, Y., \& Moonti, R. M. (2018). Pencegahan Korupsi Dalam Pengelolaan Dana Desa. Jurnal IUS Kajian Hukum dan Keadilan, 6(3), 430-442. 
districts/cities, as well as grants and donations obtained from the third parties. The income will be used to fund all village finances which include village governance, development of the village, and social empowerment. the village also has the authority to manage its needs in accordance with the scale of priority.

To realize the orderly, transparent, accountable, and good quality management of village funds, the government has the authority to impose sanctions on the users of village funds, Besides the regional, district, and city government can also impose sanctions in the form of reducing village funds if they not using the funds appropriately according to the priority needs, general guidelines, technical guidelines for the activities, or derivations in the form of deposit exceeding the 2 months. Regarding the accountability of the implementation of APBDes, several provisions need to be considered, such as:

1. The Head of the Village must take the responsibility for the realization of the use of the budget that will be done at the end of the budget year;

2. The elements of the accountability report on the implementation of APBDes consist of expenditure and outlay;

3. The APBDes accountability report is stipulated in the form of a village regulation with the attachment of the format of accountability report on the realization of the APBDes implementation; report on assets owned by the village and report of government or regional programs that involving the village;

4. Accountability report of the implementation of APBDes that will be informed to the public by the media that are accessible such as pasted on the information board, community radio and other media;

5. The APBDes report is submitted to the regent through the head of sub-district.

Overcoming this problem requires a clear and detailed regulation related to the management of village funds, in the form of government regulations, regional regulations, and even regulations that are implemented at the village level so that the management of village funds runs well. In drafting regulations related to village fund management, it is also necessary to pay attention to the potentials that could have an impact on the misuse of village funds, both in terms of the readiness of the implementer of village fund management, the stage of village fund management planning, the stage of implementation of village fund management, until the stage of accountability village fund.

\subsection{Prevention Measures Against Village Funds Deviation}

Supervision of the implementation of Government functions is not only intended to make an effort to avoid mistakes both intentionally or unintentionally but also as an effort to make improvements if there is a mistake found so that the surveillance contains both preventive and repressive intentions. ${ }^{15}$ The intended surveillance in the form of laws governing and limiting governmental authority covering both material and formal law. ${ }^{16}$ The surveillance process that is based on clear benchmarks, if the signs of deviation from the benchmarks are discovered, a preventative measure is taken and if deviations occur

${ }^{15}$ Lotulung. P.E. (1993). Beberapa Sistem Tentang Kontrol Bagi Hukum Terhadap Pemerintah. Bandung : Citra Aditya Bakti. p. XV.

${ }^{16}$ Rahayu, D. P. (2015). Pengawasan Preventif Sebagai Kontrol Pusat Terhadap Daerah Di Era Reformasi. Padjadjaran Journal of Law, 2(3), 444-462. DOI: https://doi.org/10.22304/pjih.v2n3.a2 
from the benchmarks, corrective action will be taken in the form of cancellation, retrieval from the deviation effects, and handle the perpetrators. ${ }^{17}$

The notion of surveillance has been widely formulated by experts in various literature. One of them is according to Mocker who believes controlling is a systematic effort by business management to compare performance to pre-determined standards, plans, or objections to determine which performance is in line with these standards and presumably to take any remedial action required to see that human and other corporate resources are being used to be the most effective and efficient way possible in achieving corporate objectives. ${ }^{18}$ From the above matters, it can be said that supervision must be preceded by a work plan, foals and standards as benchmarks for the work process to achieve the goals of the organization. Between plans and work results will be compared, if found any errors, then an action of improvement must be made).

Supervision is a very important thing in making efforts to prevent the deviation in village funds. In its application, supervision must fulfill the characteristics of the monitoring process itself so that it can run effectively and producing the results that in accordance with the objectives of the surveillance itself. The characteristics of a monitoring process usually containing several substances that can be described as follows: 19

1. Surveillance must be conducted as finding, where the implementation of the surveillance function must find the formulation of tasks to run the organization, with the influence of other factors such as the system;

2. Running the surveillance must be preventive, meaning that the monitoring process is carried out to prevent a deviation and misuse of the plan;

3. Surveillance must be directed to the present, meaning that supervision can only be aimed at the activities that are being carried out;

4. Surveillance in the form of a tool to achieve efficiency, not as a goal;

5. Surveillance is an administrative and management tool so that the implementation of the surveillance aims to make it easier to find the goals;

6. Implementation of surveillance must be efficient;

7. The existence of surveillance is not intended to find out who is wrong but find out what is not right;

8. Surveillance has the nature of guiding so that the implementer of the activity can improve in carrying out his duties.

To make the surveillance effective, especially to prevent the deviation or fraud in this case village funds, then a supervisor is expected to have integrity and professionalism. Integrity is the basic trait that must be possessed by someone intact, where someone's personality should not be compartmentalized but must have consequences in the dimension of his life.

17 Silalahi, D. M. (2020). Kompetensi Peradilan Tata Usaha Negara Terhadap Pengawasan Penyelenggaraan Pemerintahan Ditinjau Dari Perluasan Asas-Asas Umum Pemerintahan Yang Baik Pasca Berlakunya Undang-Undang Nomor 30 Tahun 2014 Tentang Administrasi Pemerintahan. Jurnal Komunikasi Hukum (JKH), 6(1), 50-63. DOI: http://dx.doi.org/10.23887/jkh.v6i1.23439

${ }_{18}$ Ceto. S.C and Ceto. S.T. (2006). Modern Management, Person Prentice Hall. New York. p. 80.

${ }^{19}$ Siagian. S. P. (1996). Patologi Birokrasi. Jakarta : Bumi Aksara. p.114. 
People who have integrity are people who have an honest view of life in harmony in thoughts and actions, they won't lie, trustworthy, can not be bought and independent. Whereas what is meant by a professional is a person who has skills in a field, has knowledge and experience and has the skills to analyze a problem, so that he can make a future-oriented decision quickly and accurately. Someone can be said to have a high level of professionalism if they can achieve an adequate level of moral integrity, because professionalism not only has expertise but quality in work that exceeds their expertise. To identify the characteristics of the people who have the ability to moral integrity among others are: they are not cheating, not betraying, honest, not deceptive and hypocritical, humble, not pretentious and does not make a negative impression, responsible and always giving their best in completing their work in accordance with the standards of quality. ${ }^{20}$

Prevention of crime is essentially an integral part of efforts to protect society (social welfare), not merely criminal law enforcement. ${ }^{21}$ So that efforts to overcome and prevent crime in general can be divided into two, which are, litigation (criminal law) and non penal. The efforts to prevent crime through penalties are more focused on repressive measures (eradication or repression) after a crime has taken place, while non-criminal efforts are more focused on prevention/deterrence/control before the crime occurs. Whereas in this research the efforts are directed towards prevention of deviation in village funds through non-penal channels, with an emphasis on the importance of supervision in managing village finances by paying attention to several things including:

\subsubsection{Conformity of the Determination of the Use of Village Funds}

Conformity in the use of Village Funds is based on the village authority. The intended village authority is that the authority in managing the finance of the village is limited to the affairs of village authority based on the origin and the authority of the village. Compliance with procedures for determining village authority is based on:

1. District/city regional Government identifies and inventory authority based on original rights and local authorities involving villages;

2. Based on the results of the identification and inventory of village authorities, regents/mayors on the list of authorities based on original rights and local authority of village scales in accordance with statutory regulations;

3. Regulations of the regen/mayor are followed up by the village administration by stipulating village regulations regarding authority based on the origin and authority of the village scale according to the situation, conditions and local needs.

The activities funded by village funds must be based on the authority stipulated by village regulations, therefore all activities financed by village funds must be included in the list of

20 Arif, A. (2005). Pendidikan Berwawasan Moral Menghasilkan Sdm Anti Korupsi. Jurnal Ilmu Administrasi: Media Pengembangan Ilmu dan Praktek Administrasi, 2(3), 03.

DOI: https:// doi.org/10.31113/jia.v2i3.457

${ }^{21}$ Firmansyah, A., \& Suhardiman, E. D. (2015). Membangun politik kriminal pada pertambangan batubara yang menyejahterakan masyarakat melalui sarana non-penal. Fiat Justisia: Jurnal Ilmu Hukum, 9(3). DOI: https://doi.org/10.25041/fiatjustisia.v9no3.601 
village authorities so that the village has the authority to make a village regulations that regulate the use of village funds for the activities that using village funds.

\subsubsection{Appropriate Use of Village Funds as Part of Village Planning}

Under the Village Law, the Government of the village is required to make village development planning in accordance with its authority with reference to district/city development planning. The midterm development of the village and the government work plans of the village are stipulated by village regulation which becomes the document of village planning. The plan must be clearly funded from village funds. The determination of the use of village funds must go through the deliberation. Village planning is carried out based on village authority whose decision making must be carried out through village deliberation. Village Consultative Body (hereinafter referred to as BPD), the government of the village, and the element of the society attend a meeting to discuss and agree on the strategic matters and based on village authority that is funded by village funds.

\subsubsection{Conformity in the Use of Village Funds Regulated in Village Regulation}

Regarding the determination of the policies carried out by the government of the village concerning the use of village funds formed in village regulation, prepared by the Head of the Village and the BPD. The BPD together with the Head of the Village is obliged to ensure the village deliberation decision on the use of village funds to be the basis in the preparation of village regulation that containing village work plans and village regulation on the village budget. The decision made at the village meeting must be accommodated and channeled the aspiration of the villagers that were used as the basis for drafting the village regulation. Village regulation concerning village work plans and village regulation on village budget and income must be made in accordance with the interest of the public in general and must follow the higher regulation. Related to the arrangements for the use of village funds must be prepared in the interest of the public in general and following the higher regulation. The regulation of the use of village funds in carried out village work plans and village income budget must not conflict with the interest of the public in general and/or the higher statutory provisions. If there are things that have conflict, with the result of surveillance must be canceled by the regent/mayor.

\subsubsection{Monitoring and Surveillance of Village Administration}

Government surveillance is carried out village development will be done in a participatory manner by the villager, including:

1. Monitoring society-based village governance;

2. Conducting society-based audits;

3. Developing an audit system for village complaints;

4. Developing legal assistance to solve the problem independently;

5. Make a village deliberation to account and hand over the results of village development and

6. Conducting other activities that are in accordance with the authority of the village decided in the meeting. 
Give priority to the preparation of planning and budgeting in favor of the interests of the poor, disabilities, women and children, and marginalized groups. The alignment can be done by organizing deliberation in those groups to prepare a proposal and carried out other activities in accordance with the village authority which is decided in village deliberation.

\subsubsection{Work Steps}

In carrying out the surveillance, it must also determine how the steps to be taken to the implementation of surveillance has a mechanism as a guideline in its implementation as follows:

1. Checking the technical officers of the village financial management that appointed from elements of the village apparatus consist of Secretary of the Village, Head of the Village, and treasurer that assigned based on the decision of the Head of the Village;

2. Checking the priority of village funds of Village Regulation on the Village midterm development plan;

3. Examine the suitability of the APBDes and Village Government Work Plan or Village Development Work Plan;

4. Tracing the distribution of village funds by the regency/city to the Head of the Village has been carried out by transferring a report from Regional General Cash Accounts to the village account;

5. Tracing the revenue and expenditure of funds has been done by village treasury account;

6. Checking the village service area which doesn't have any banking services yet, the implementation of village revenue and expenditure activities are managed with a mechanism;

7. Tracing the revenue and expenditure of village funds has been supported by complete and valid evidence;

8. Checking the expenditure that must be done before drafting the Village regulation concerning APBDes;

9. Checking the submission of expenditure of village funds accompanied by documents including the Budget Plan and verified by the Head of the Village;

10. Search for budget expenditure has been preceded by submitting a request for Payment Order to the Head of the Village;

11. Checking the filling of Payment Order has been attached with a statement of expenditure responsibility and attached with the proof of transaction;

12. Perform proof of transaction, both material and formal;

13. Checking the procurement of good and services has been done by maximizing the use of materials from the local area; 
14. Examine the procurement of good and services with mutual cooperation by involving the society to expand employment opportunities and empower local communities;

15. Verifying the completeness of the planned implementation of the selfmanagement procurement of goods and services including: schedules, plans for personnel use, equipment, working plan, etc;

16. Verifying the completeness of the construction of work requirements documents;

17. Examine the provider of goods and services deemed capable of carrying out the supply of goods and services and have fulfilled the requirements such as having a location of business, etc;

18. Examine the Budget plan related to conformity with local market place;

19. Checking the technical verification of the goods and services;

20. Checking the change in scope of work;

21. Examine the payments the procurement of the goods and services through its providers carried according to the applicable provisions;

22. Check the progress of the procurement of the goods and services reported by Activity Implementation Team to the Head of the Village;

23. Checking the hand over of the goods and services to the Head of the Village in an official report;

24. Checking on expenditure of the village funds for development or construction and other capital expenditure from village funds;

25. Checking the Treasurer of the Village work in recording the revenue and expenditure;

26. Make sure the Treasurer of the Village has recorded revenue and expenditure of the village funds and close the books periodically;

27. Checking the accountability report;

28. Analyze the provided benefits of village funds to the society;

29. Make sure that the Treasurer is a taxpayer;

30. Examine the tax calculation;

31. Checking the complement of tax obligations, next make a conclusion.

The right to society's involvement in overseeing the use of the budget is an important factor in preventing the occurrence of deviation in village funds. Begin with the right of participatory of society involvement in the budgeting process, the availability of budget allocation that in favor with the poor, transparency and accountability in the management and accountability of the APBDes to the society, and the existence of the oversight of the society regarding the implementation of the APBDes, both individually and institutionally. Furthermore, to control or oversee the APBDes to avoid deviation or to avoid corruption in the village, three principles can be used, such as:

1. Wetmategheid, is a principle of supervision that emphasizes the importance of aspects of conformity between the practice of implementing the APBDes in accordance with the applicable law and regulation; 
2. Rechmategheid, is the principle of surveillance which focuses on the legality of the practice of implementing the APBDes by examining the legal basis of every aspect of APBDes implementation;

3. Doelmategheid, is the principle of surveillance that emphasizes the importance of the role of benchmarks in the practice of implementing the APBDes.

Referring to that three principles are highly recommended for the people who want to participate in controlling the implementation of the budget, should prepare legal products related to the APBDes, or which are the basis for the preparation of the APBDes. These legal products besides village regulation on APBDes are also rules relating to the implementation of development activities in the village. In addition, evaluation is also very important. The evaluation aims to see the extent of compatibility between the plan and the target to be achieved both regarding revenue and expenditure. Steps that can be taken by the society to play a role in control at the evaluation stage including it is necessary to know the audit results documents from the audit institutions, then see which one has been followed up if no further action has been taken, the reasons for this need to follow up; read the accountability report then analyzed how far the truth of the report that in accordance with the fact; likewise, the extent to which complaints or deviation in development or deviation from the use of the budget has been used; furthermore, it should also be monitored the auditors work well. If bribery is found, it can be reported if there is sufficient evidence.

With the surveillance of the society or other parties, it will prevent any deviation or corruption of village funds. It will also increase the efficiency and effectiveness of the use of the budget so that it will improving the quality of development which will ultimately bring the lives of people, especially in the village towards equitable prosperity.

\section{Conclusion}

Some things that have the potential for corruption of village funds that can harm the country's finances include the first because of the unpreparedness of the village government in managing village funds ranging from diverse village culture, lack of technical assistance, the ability to manage village officials, welfare and skills of village heads to the coordination system interrupted, then the second potential is in terms of planning that does not involve the community and the role of the Village Consultative Body, the third implementation, in this case, the implementation of the use of village funds still does not follow the existing procedures and the existence of budget politicization, and the fourth is in terms of accountability With the limitations of the village apparatus, this is often ignored and even if carrying out the accountability is not made as much as possible. In the case of efforts to prevent misuse of village funds, it is necessary to have a preventive effort, namely prevention by checking the suitability of the determination of village funds, the suitability of the use of village funds with what is planned, the suitability of the use of village funds to the rules, monitoring the implementation of village governance and ensuring work steps. This study offers an effort to prevent irregularities in village funds through non-penal channels, with an emphasis on the importance of supervision in managing village finances. So the need for a regulatory regulation to avoid undesirable things that can disrupt and harm the country's finances. 


\section{Reference \\ $\underline{\text { Books }}$}

Ceto. S.C and Ceto. S.T. (2006). Modern Management, Person Prentice Hall. New York.

Jaya. N. S. P. (2008). Beberapa Pemikiran ke Arah Pengembangan Hukum Pidana. Bandung : Citra Aditya Bakti.

Lotulung. P.E. (1993). Beberapa Sistem Tentang Kontrol Bagi Hukum Terhadap Pemerintah. Bandung : Citra Aditya Bakti.

Siagian. S. P. (1996). Patologi Birokrasi, Jakarta : Bumi Aksara.

\section{Journal}

Alkostar, A. (2008). Mengkritisi fenomena korupsi di parlemen. Jurnal Hukum IUS QUIA IUSTUM, 15(1). DOI: https:// doi.org/10.20885/iustum.vol15.iss1.art2

Anggono, B. D. (2020). Omnibus Law Sebagai Teknik Pembentukan Undang-Undang: Peluang Adopsi Dan Tantangannya Dalam Sistem Perundang-Undangan Indonesia. Jurnal RechtsVinding, 9(1).

Anggraeni, T. D. (2014). Menciptakan sistem pelayanan publik yang baik: Strategi reformasi birokrasi dalam pemberantasan korupsi. Jurnal Rechts Vinding: Media Pembinaan Hukum Nasional, 3(3), 417-433.

Arif, A. (2005). Pendidikan Berwawasan Moral Menghasilkan Sdm Anti Korupsi. Jurnal Ilmu Administrasi: Media Pengembangan Ilmu dan Praktek Administrasi, 2(3), 03. DOI: https://doi.org/10.31113/jia.v2i3.457

Firmansyah, A., \& Suhardiman, E. D. (2015). Membangun politik kriminal pada pertambangan batubara yang menyejahterakan masyarakat melalui sarana nonpenal. Fiat Justisia: Jurnal Ilmu Hukum, 9(3). DOI: https://doi.org/10.25041/fiatjustisia.v9no3.601

Hadi. K. (2016) Korupsi Birokrasi Pelayanan Publik di Era Otonomi Daerah. Jurnal Penelitian Politik, 7 (1), 20.

Kadir, Y., \& Moonti, R. M. (2018). Pencegahan Korupsi Dalam Pengelolaan Dana Desa Jurnal IUS Kajian Hukum dan Keadilan, 6(3), 430-442. DOI: http://dx.doi.org/10.29303/ius.v6i3.583

Khaidir, K., Abdullah, M., \& Achmad, R. (2017). Kebijakan Hukum Pidana Dalam Pemberantasan Tindak Pidana Korupsi (Tinjauan Analisis Terhadap Pembalikan Beban Pembuktian Dalam UU Nomor 20 Tahun 2001). Legalitas: Jurnal Hukum, 1(5), 92-131.DOI: http://dx.doi.org/10.33087/legalitas.v1i5.78

Milono, A. (2014). Formulasi Pedoman Penjatuhan Sanksi Pidana terhadap Penyelenggara Negara yang Melakukan Tindak Pidana Korupsi di Indonesia. Arena Hukum, 7(1), 117-130. DOI : https://doi.org/10.21776/ub.arenahukum.2014.00701.7

Nastiti, N. N., Djemat, Y. O., \& Dwiprigitaningtias, I. (2017). Tantangan Implementasi Kerjasama Anti-Terorisme Antara Indonesia dan Australia Tahun 2007-2016. Jurnal Dinamika Global, 2(02), 68-112.

Rahman, F. (2011). Korupsi di tingkat desa. Jurnal Ilmu Pemerintahan Governance, 2(1), 13-24.

Roza, D., \& Arliman, L. (2017). Peran Badan Permusyawaratan Desa di Dalam Pembangunan Desa dan Pengawasan Keuangan Desa. Padjadjaran Journal of Law, 4(3), 606-624. DOI: https:// doi.org/10.22304/pjih.v4n3.a10

Sayuti, A. H. Y. (2014) Rekonstruksi Sistem Pengawasan Pemerintah Desa Berdasarkan Undang-Undang Nomor 6 Tahun 2014 tentang Desa Berbasis Prinsip Good Village 
Governance. Kumpulan Jurnal Mahasiswa Fakultas Hukum, 1 (1). http://hukum.studentjournal.ub.ac.id

Silalahi, D. M. (2020). Kompetensi Peradilan Tata Usaha Negara Terhadap Pengawasan Penyelenggaraan Pemerintahan Ditinjau Dari Perluasan Asas-Asas Umum Pemerintahan Yang Baik Pasca Berlakunya Undang-Undang Nomor 30 Tahun 2014 Tentang Administrasi Pemerintahan. Jurnal Komunikasi Hukum (JKH), 6(1), 50-63. DOI: http://dx.doi.org/10.23887/jkh.v6i1.23439

Sosiawan, U. M., \& Indonesia, H. A. M. R. (2019). Peran Komisi Pemberantasan Korupsi (KPK) dalam pencegahan dan pemberantasan korupsi. Jurnal Penelitian Hukum De Jure, 19(4), 517-538. DOI: http:/ / dx.doi.org/10.30641/dejure.2019.V19.517-538

Yulianah, Y. (2017). Potensi Penyelewengan Alokasi Dana Desa di Kaji Menurut Peraturan Menteri dalam Negeri Nomor 37 Tahun 2017 tentang Pengelolaan Keuangan Desa. Jurnal Hukum Mimbar Justitia 1(2), 608-627.

\section{Statutory Law}

Law Number 6 Of 2014 Concerning Villages Supplement To State Gazette Of The Republic Of Indonesia Number 5495.

Government Regulation of The Republic of Indonesia Number 8 of 2016 About second change to Government Regulation Number 60 of 2014 toncerning Village Fund Sourcing From State Revenue And Expenditure Budgets Supplementary To State Gazette Of The Republic Of Indonesia Number 5864. 